\title{
Corpo, ritmo e voz na leitura de poemas
}

Children's poetry in the labyrinths of the digital world: possibilities and challenges

\section{Gláucia Regina Raposo de Souza}

Universidade Federal do Rio Grande do Sul - UFRGS - Rio Grande do Sul - Brasil

\begin{abstract}
Resumo: Trata-se de um ensaio livre sobre a leitura de poemas entre leitores iniciantes, a partir da experiência e dos estudos da autora como leitora, como professora e como escritora.
\end{abstract}

Palavras-chave: Leitura de poemas, leitura infantil, escrita de poemas.

Abstract: It is a free essay on the reading of poems among beginning readers, based on the author's experience and studies as a reader, as a teacher and as a writer.

Keywords: Reading poems, reading children, writing poems.

\author{
O poema na escola: \\ festa cívica, primavera, \\ dia útil, nova era. \\ O poema em casa: \\ brincadeira diferente, \\ fala truncada na boca, \\ dança de sons, \\ presente
}

Escrevi este poema por ocasião da escrita da tese de Doutoramento intitulada Uma viagem através da poesia: vivências em sala de aula, apresentada por mim em 2007 ao Programa de PósGraduação em Letras da pontifícia Universidade Católica do Rio Grande do Sul, na área de concentração de Teoria da Literatura, sob orientação da Professora Doutora Vera Teixeira de Aguiar.

Passados doze anos, relendo o poema, percebo que ele traduz de forma sintética minhas memórias de infância acerca de meus primeiros contatos com o poema. Fala, também, sobre como a poesia entrou na minha vida e por ela seguiu, ao longo de minha trajetória de professora, de leitora, de escritora. E são estes os três eixos que traço, ainda que de forma rápida, para tecer estas breves reflexões.

Começo já pela idade adulta, relembrando a professora. Através de minha prática docente, pude observar, em crianças de nove a doze anos, certa resistência à leitura de poemas, sobretudo quando ingressavam no segundo segmento do Ensino Fundamental. Muitas delas, inclusive, alegavam não gostar de poemas. Contudo, observei, também, uma necessidade de que essas crianças lessem em voz alta os textos trabalhados em sala, como atitude precedente a sua leitura silenciosa. Muitas vezes, essa leitura oral preliminar transformava-se em prérequisito para uma melhor compreensão do texto.

Percebi, através de diferentes leituras, que tal atitude se aproximava, de certa forma, daquela feita pelos leitores das escritas sem separações, tais como as da Grécia e da Roma antigas. Ao se verem em situação de leitura, muitos pré-adolescentes sentiam necessidade do suporte do som, tal como observa Saenger (1997, p. 219). Precisavam da leitura em voz alta ou do balbucio para terem acesso à compreensão do texto. Faziam, portanto, uma leitura 
em que oral e escrito estavam entrelaçados, na medida em que era a voz que instaurava o sentido do que liam, em virtude de seu estágio de alfabetização.

Percebi também que, quando solicitadas a falarem ou a escreverem sobre se conheciam algum poema, essas crianças traziam de memória quadras populares, pequenos poemas escritos em agendas e em folhas de anotações pessoais. Para mim, surgiu a suspeita de que havia um descompasso entre o que a escola queria que as crianças considerassem como poema (a peça literária autoral, escrita e discutível em sala de aula) e o que elas realmente tinham em suas mãos como poema (versos, na maioria das vezes rimados, sem autoria determinada, guardados na memória ou partilhados em agendas).

Por esse motivo, tentei descobrir que concepções sobre o poema estavam presentes entre estudantes dos anos finais do Ensino Fundamental. Para eles, poemas eram "aquilo que expressa emoção". Também declararam pouco ouvir poemas, embora, muitas vezes, tivessem necessidade de os ler em voz alta, de ritualizar suas leituras, para que se aproximassem, assim, da oralidade. Ainda que tivessem relatado pouco ouvir poemas, tais préadolescentes referiram-se a familiares próximos, a amigos, enfim, a pessoas com quem mantinham laços de afeto, como pessoas que lhes proporcionaram o contato auditivo com poemas. Tais pessoas atuavam como vocalizadores da palavra escrita, o que, de certa forma, aproxima-se da prática de leitura em voz alta, freqüente no século XVII que, segundo Chartier (1991), fortalecia a intimidade familiar e a de pequenos grupos sociais:

Minha memória voltou-se, então, para meus próprios afetos, os meus primeiros grupos de pertença, os quais proporcionaram meus contatos iniciais com a poesia.

Quando eu era pequena, gostava de ouvir histórias contadas pela minha família e, também, de cantar poemas e de brincar com as palavras junto com meus amigos, com minha irmã e minha prima, através de desafios de trava-línguas. De cada ninho de mafagafos, sempre brotavam sete mafagafinhos. Também gostava de construir escadas com os livros da casa, que subiam em direção aos castelos das histórias de fadas que eu ouvia em minha pequena vitrola, através da qual também podia conhecer cantigas de roda de outros tempos e lugares. Se me perguntassem o que era um poema, ou como eu definia poesia, não saberia dizer; apenas sabia que: "A mão direita tem uma roseira, que da flor na primavera", ou então "Quem quer casar com a Senhora Baratinha, que tem fita no cabelo e dinheiro na caixinha".(Barro, 2002).

Estes eram os meus momentos mágicos em casa, quando, ainda sem saber, convivia com os sons, os ritmos e o sentido figurado dos poemas cantados e dançados em brincadeiras de palavra e de roda. No entanto, eu-menina, na escola, pouco lia naquela época, principalmente poemas, presentes apenas nas horas cívicas, como forma de homenagear algum fato histórico, alguma data festiva, ou algum bom hábito de higiene ou de convivência social.

Faltava-nos, na escola, a poesia primitiva, tal como a concebe Spina. Através da poesia primitiva, um mesmo poema é de um indivíduo através da escrita, mas apenas depois de ser de muitos através da fala. Por transitarem entre a recepção individual e a coletiva, não é de se estranhar que os poemas que circulam entre as crianças sejam, em sua maioria, de tradição popular (quadras, trava-línguas e ditos populares). Talvez isso ocorra porque, de certa forma, tais poemas que circulam entre crianças aproximamse do que Spina (1982) classifica como poesia primitiva: aquela que não é só a dos povos préletrados, mas, também, a que está ligada ao canto, que é indiferenciada, anônima e coletiva.

Para Spina, "a poesia primitiva é uma poesia de caráter coletivo, porque representa os anseios da coletividade e está intimamente ligada ao modus vivendi dessas comunidades(...)" (p.2). Estão presentes na poesia primitiva os elementos formais que representam o nascimento da poesia. São eles: a repetição, o refrão, o paralelismo, a aliteração, a assonância, a rima etc. Observamos esses elementos, no berço da poesia, nas brincadeiras 
infantis em forma de poemas e em poemas de tradição popular.

Por terem marca de oralidade, os poemas de nossa tradição oral trazem uma dupla vinculação com o corporal: através da voz (quer falada, quer cantada) e através do corpo propriamente dito (através de uma performance, como no caso das cantigas de roda, por exemplo).

Finalmente descobri que atividades relacionadas à voz e ao corpo poderiam ser um bom começo para a iniciação de estudantes à leitura e à produção de poemas. Trata-se, antes de tudo, de recuperar a voz perdida dos poemas para que possamos, assim, mediá-los junto a jovens leitores. Depois de professora, percebi que a oralidade era o caminho pelo qual muitos estudantes se aproximavam da Literatura. Isto porque as formas poéticas populares estão presentes no imaginário de qualquer grupo social. Desta forma, é comum entre as crianças brincar com ditos populares, com adivinhas, com parlendas, com cantigas de roda ou de ninar... Eu, menina, já sabia intuitivamente isso.

$E$ que podemos dizer dos textos ditos autorais? Em função desse diálogo com o universo da infância, muitos autores, de diferentes gerações, buscam inspiração nessas formas para comporem novos poemas, ou para fazerem releituras dos existentes. Marcadamente sonoros, os poemas de origem popular podem aproximar a criança de aspectos também presentes em poemas escritos por autores.

Assim fiz, também eu, como escritora. Não posso deixar de lado meu lugar de escritora, restringindo-me ao de leitora e ao de professora, pois a recepção de poemas na infância e na vida adulta conduziu-me à produção deles. Um exemplo de criação a partir de poemas orais da cultura popular é o poema "Pirata", do livro Do alto do meu chapéu. (Souza, 2011, p. 40).

Ao escrever os poemas do livro Do alto do meu chapéu, precisei pesquisar de forma mais aprofundada sobre a vida e a obra de Hans Christian Andersen, principalmente sobre suas criações em papel, os papercuts, Para tanto, busquei o acervo do
Museu de Odense, na Dinamarca, disponível online no endereço eletrônico

https://museum.odense.dk/en/collections/hanschristian-andersen-collections .

Ao visitar o acervo do Museu de Odense, pude me deparar com uma das imagens criadas por Hans Christian Andersen criadas para serem enfeites de Natal, e uma delas me transportou para meus tempos de infância:

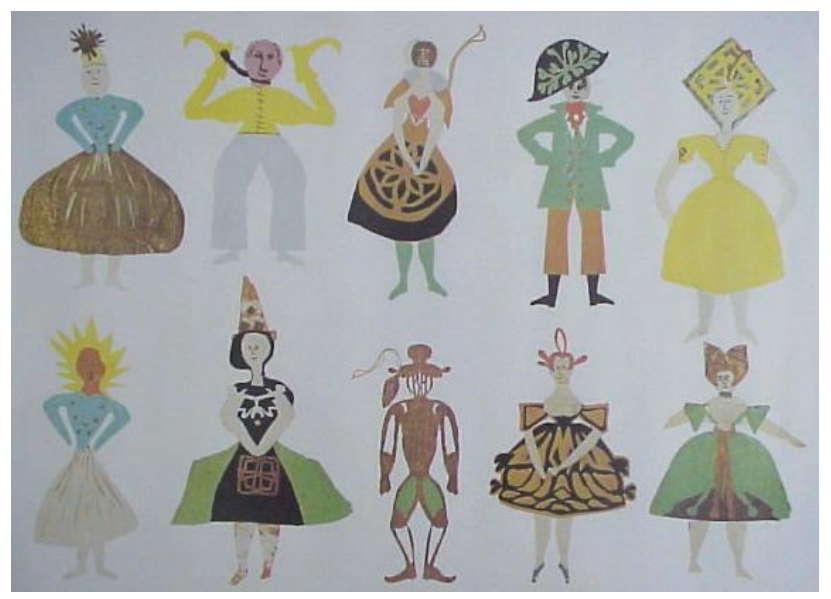

A imagem de um boneco com grande chapéu preto e casaca, lembrou-me de uma brincadeira de infância, cuja cantiga trazia os seguintes versos:

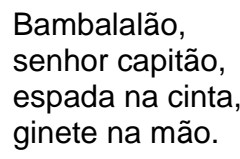

Bambalalão, senhor capitão, espada na cinta ginete na mão.

Esta cantiga foi, também, inspiração para o poema de Manuel Bandeira intitulado "Rondó do Capitão", de 1940, o qual, ainda pequena, conheci através da voz de Ney Matogrosso, quando vocalista do grupo Secos e Molhados:

\section{RONDÓ DO CAPITÃO}

Bão balalão,

Senhor capitão,

Tirai este peso

Do meu coração.

Não é de tristeza,

Não é de aflição:

É só esperança,

Senhor capitão!

A leve esperança,

A aérea esperança...

Aérea, pois não!

- Peso mais pesado 
Não existe não.

Ah, livrai-me dele,

Senhor capitão!

(Bandeira, 2008, p. 30)

A imagem de Andersen, o poema oral, 0 poema releitura feito por Bandeira e a melodia que 0 acompanhou posteriormente fizeram nascer o poema "Pirata":

\author{
Pelo mar, \\ navio e bandeira. \\ Ao remar, \\ vela e caveira. \\ Todo lugar \\ é terra estrangeira.
}

Vai o pirata lento,

onda afora,

noite adentro.

(Souza, 2011, p. 40)

Enfim, unindo as três pontas da minha caminhada entre poemas, a de professora, a de leitora e a de escritora, retomo a necessidade de a escola seguir resgatando as vivências arcaicas individuais e coletivas de leitores iniciantes, bem como as "marcas de oralidade" em seu processo de leitura. É necessário, cada vez mais, ouvir a infância: a da poesia e a nossa, de seres humanos. Só assim se poderá proporcionar aos leitores iniciantes a inserção no mundo da leitura silenciosa, no mundo que há no papel, utilizando a metáfora título do livro de David Olson (1997). Claro está que a formação do leitor/produtor de poemas não deve se restringir aos jogos de palavra. Poesia é bem mais do que isso. Georges Jean (1995, p. 56) destaca que, apesar de indispensáveis para a compreensão da poesia, tais jogos não devem constituir a atividade poética essencial na escola.

Como seres humanos, nós nos preocupamos com questionamentos acerca de nossa condição: quem somos, de onde viemos, para onde vamos. É a reminiscência que funda a cadeia da tradição (Benjamin, 1985). Desta forma, narrar nossas próprias origens, significa descobrirmos nosso eu e percebermos que este eu está tramado num nós: nossas origens.

Assim, a poesia, através de seu caráter plural, nos proporciona uma ampla reflexão acerca de nós mesmos, seja individual ou coletivamente. E isto acontece desde a poesia arcaica, que estava presente em todos os momentos da vida humana: na lida com o trabalho diário (cantos laborais), na preocupação com a origem das coisas (mitos de criação) e nos momentos de descanso e de lazer (canções de ninar e de roda).

Descobrir os diferentes sentidos das palavras de um poema é, por isso, uma tarefa essencial para que o eu leitor se identifique com o eu que se expressa, no poema, sobretudo o lírico, de modo a se colocar no lugar do outro, reconhecendo em si a "dor" do outro, como já nos disse Fernando Pessoa, em Autopsicografia: "E os que leem o que escreve,/ $\mathrm{Na}$ dor lida sentem bem,/ Não as duas que ele teve,/ Mas só as que eles não têm" (Pessoa, 1980, p. 104).

Assim, a presença da palavra poética, metafórica forma de expressão, deve ser indiscutível na vida de todos nós. Nela está a experiência que passa de pessoa para pessoa. Por este motivo, ao acolhermos a poesia em sala de aula, devemos ir além de entendê-la, buscando, antes, vivenciá-la através da oportunidade de leitura e de sua escrita; experimentá-la em nossos corpos dançantes e ouvintes. Trata-se de nos rendermos à poesia, porque:

"Há na poesia um inato poder de sedução. Graças a ele é que podemos intuitivamente chegar a entendê-la e apreciá-la. Basta apenas que a deixemos exercer o seu fascínio sobre nós." (Paes, p. 27-29)

\section{REFERÊNCIAS}

BANDEIRA, Manuel. Belo Belo e outros poemas. Rio de Janeiro: José Olympio, 2008.

BARRO, João de. A história da baratinha. São Paulo: Moderna, 2002.

BENJAMIN, Walter. O narrador: considerações sobre a obra de Nikolai Leskov.

In: _ Obras escolhidas: magia e técnica, arte e política. São Paulo: Brasiliense, 1985.

CHARTIER, Roger. As práticas da escrita. In: ARRIĖS, Philippe; BUBY, Georges (dir). História da 
vida privada. v.3. São Paulo: Companhia das Letras, 1991. p. 113-161.

JEAN, Georges. Na escola da poesia. Lisboa: Instituto Piaget, 1995.

OLSON, David. O mundo no papel: implicações conceituais e cognitivas da leitura e da escritura. São Paulo: Ática, 1997.

PAES, José Paulo. Poesia para crianças. São Paulo: Giordano, 1996.

PESSOA, Fernando. O eu profundo e os outros eus. 12ed. Rio de Janeiro: Nova Fronteira, 1980.

SOUZA, Gláucia de. Do alto do meu chapéu. Porto Alegre: Projeto, 2011.

SPINA, Segismundo. Na madrugada das formas poéticas. São Paulo: Ática, 1982.

SAENGER, Paul. A separação entre as palavras e a fisiologia da leitura. In: OLSON, David; Torrance, Nancy. Cultura escrita e oralidade. 2 ed. São Paulo: Ática, 1997. p. 211-227.

\section{COMO CITAR ESSE ARTIGO}

DE SOUZA, Gláucia Regina Raposo. CORPO, RITMO E VOZ NA LEITURA DE POEMAS. Signo, Santa Cruz do Sul, v. $45, \quad$ n. 83 , set. 2020. ISSN 1982-2014. Disponível em: <https://online.unisc.br/seer/index.php/signo/article/view/14934>. Acesso em: doi: https://doi.org/10.17058/signo.v45i83.14934. 